\title{
4C's Skills Performance Assessment in STEM Learning in Elementary School
}

\author{
Ghullam Hamdu*, Dindin Abdul Muiz L, Gina Silma N \\ Universitas Pendidikan Indonesia, Tasikmalaya Campus, Indonesia
}

Received September 30, 2020; Revised November 21, 2020; Accepted December 6, 2020

\section{Cite This Paper in the following Citation Styles}

(a): [1] Ghullam Hamdu, Dindin Abdul Muiz L, Gina Silma N , "4C's Skills Performance Assessment in STEM Learning in Elementary School," Universal Journal of Educational Research, Vol. 8, No. 12A, pp. 7668 - 7675, 2020. DOI: 10.13189/ujer.2020.082553.

(b): Ghullam Hamdu, Dindin Abdul Muiz L, Gina Silma N (2020). 4C's Skills Performance Assessment in STEM Learning in Elementary School. Universal Journal of Educational Research, 8(12A), 7668 - $7675 . \quad$ DOI: 10.13189/ujer.2020.082553.

Copyright $\odot 2020$ by authors, all rights reserved. Authors agree that this article remains permanently open access under the terms of the Creative Commons Attribution License 4.0 International License

\begin{abstract}
The performance assessment rubric is used to assess the $4 \mathrm{C}$ 's of the 21 st century skills. The rubric is used as a tool to measure the achievement of the 21 st century competences. The aim of this research is to develop $4 C$ 's skills performance assessment rubric in STEM learning in elementary school. The method used in this research is Educational Design Research (EDR) which according to McKenney \& Reeves consists of three stages, namely analysis and exploration, design and construction, and evaluation and reflection. The data collection process was carried out by conducting interview and expert evaluation. This study results in a student performance assessment rubric which includes the criteria, scores, and score descriptions. Product testing was carried out by performing the Kendall's concordance test by using the SPSS program (Statistical Package for Social Sciences) which mostly showed the Asymp.Sig $<0.05$ and can be interpreted that there is an agreement. This research concludes that the performance assessment rubric can be used to assess the 21st-century skills in STEM learning.
\end{abstract}

Keywords Rubric, Performance Assessment, 4C's Skills

\section{Introduction}

In the 21st century, technology is crucial for facing globalization era. Therefore, it is necessary to introduce technology in elementary schools to encourage students to be ready to face the challenges of globalization in everyday life [10]. STEM education approach is teaching and learning content, also the practice of interdisciplinary knowledge including sciences and math through engineering and design practice integration by using relevant technology engineering [3]. Thus, STEM (Science, Technology, Engineering, and Mathematics) learning is one of the solutions to facing the challenges of the 21st century. The STEM approach seeks to develop and provide innovative solutions to global problems, especially those directly related to the Industrial Revolution 4.0 [10]. STEM learning is very relevant to the 21 st century skills development. Skills related to STEM are: math, science, critical thinking, active learning, complex problem solving, and technology design [4]. This is in line with the statement of Musa, Mufti, Latiff, \& Amin [18] who suggest that "21st century skills require creativity, persistence, and problem solving combined with good teamwork". STEM education helps students in developing skills of the $21^{\text {st }}$ century that have capacities for innovation and allows students in problem-solving and quantitative reasoning [17].

In a study conducted by Han, Capraro, \& Capraro [8], it was found that developing STEM learning was one of the most significant challenges faced by teachers along with improving student performance in the fields of science, mathematics, and engineering. Therefore, the assessment of learning outcomes needs to focus on authentic assessment, especially on performance assessment because it is necessary for STEM learning [19]. STEM approach gives positive impacts in the scientific process, 
investigation skills, and creative thinking of students. Also, it also develops student's reasoning skills, critical thinking skills, creativity, innovation, scientific literacy effects to students, and problem-solving skills [3]. Performance assessment is a benchmark for teachers in determining student learning outcomes that "acquire and demonstrate progress in 21 st century skills" [12]. Therefore, the assessment is carried out by assessing student performance based on the 4C's skills criteria. The assessment should be able to evaluate student performance to ensure that students acquire and demonstrate progress in the 21st century skills [12].

An assessment that can be used to assess all aspects starting from input, process, to output in learning is called authentic assessment [16]. Authentic assessment is carried out by the teacher to realistically assess everything that students have done, both process and outcome. Authentic assessment must reflect the real world and not only measure what students know but also strongly emphasize on measuring what students can do [13]. Authentic assessment changes the role of students, from passive to active, as they actively collaborate and participate in evaluating their progress [1]. Hart [9] further states that authentic assessment challenges students to complete authentic tasks that are interesting, useful, and relevant to their lives.

One form of authentic assessment is performance assessment which requires students to answer questions by showing or demonstrating their skills and knowledge [13]. Authentic assessments require students to be effective performers with acquired knowledge [1]. Therefore, performance assessment is considered capable of encouraging students to provide answers by showing or demonstrating knowledge and skills or performance in a learning process [11]. Performance assessment is suitable to be used to measure the achievement of competencies that require students to do certain tasks that focus on motor skills. Therefore, performance assessment is designed to facilitate students to "learn how to study" [20]. Performance assessment measures the ability to communicate, solve a problem, and conduct critical thinking, in other words, performance assessment improves meta-cognitive skill as it leads the way students study [20]. According to Marzano [14] performance assessment is effective for measuring the ability that is not detected in paper and pencil test.

The current curriculum in Indonesia requires teachers to have adequate knowledge of 21 st century skills. Therefore, the role of teachers in carrying out the learning process is to direct students to possess and develop the 21 st century skills. The 21 st century skills that need to be develop are called the 4C's skills (Creativity, Critical Thinking, Communication, and Collaboration). Since these skills are learning abilities that can bring students to be successful in working and career in the era of the global economic community and become citizens who are ready to face the challenges of the 21 st century [21, 23, and 24]. This is in line with Griffin, McGaw, \& Care [2] who categorizes the 21 st century skills one of which is the way of working which includes communication, collaboration and teamwork skills. Thus, the 21 st century skills assessment is needed to assess the growth and development of individual students from low-level skills to high-level skills [5].

The field study conducted in elementary school in Indonesia revealed information regarding STEM learning and performance assessment. It was found that STEM learning had not been implemented in the elementary school and there was no STEM learning assessment instrument available. Therefore, this study aims to develop a performance assessment instrument in the form of a proper assessment rubric with clear instructions and assessment criteria. It is expected that this instrument can assist teachers in conducting assessments which focuses on STEM (Science, Technology, Engineering and Mathematics) and also refers to assessments that align with the demands of the curriculum in Indonesia in relation to the 21 st century skills.

\section{Method and Discussion}

The research method used in this study was Educational Design Research (EDR) with qualitative and quantitative approaches. Researchers in this study developed a performance assessment rubric for measuring the 4C's skills in STEM learning with the learning media utilised was the steam powered boats. Data collection process was carried out through interviews, expert validations, and observations. Product analysis was carried out by calculating the concordance with the Kendall's test. This Kendall's test was conducted using the SPSS version 24 program. This study refers to the EDR development model according to McKenney \& Reeves [15]. The design used is as follows:

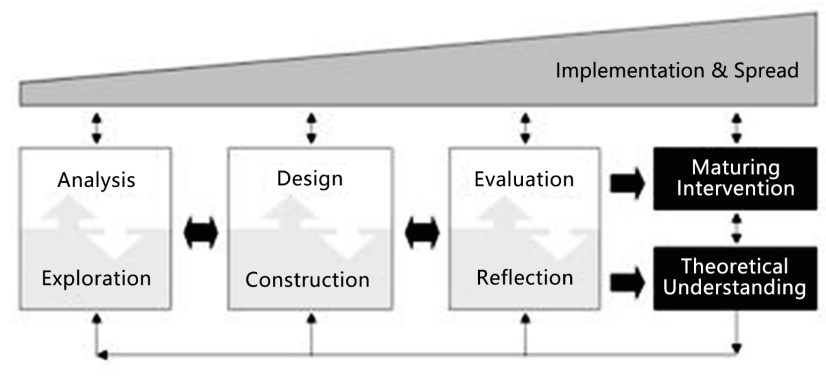

Figure 1. Generic Model of EDR

Figure 1 shows that the EDR research process has three main stages. The following are the stages of the research that has been carried out:

\subsection{Analysis and Exploration Stage}

At this stage, the researchers analyzed the and explored the problem through literature studies and preliminary 
studies to an elementary school in Indonesia. Based on the results of the analysis and exploration of the problem that had been carried out, it was found that the STEM learning had not been implemented and even the performance assessment instrument in the form of a rubric had not been available yet. Whereas, in the Indonesian curriculum, the assessment used is authentic assessment which takes into account the balance between knowledge, attitudes, and skills dimensions. The implementation of performance assessment process is still hindered by obstacles, especially in the process of assessing student learning outcomes. Performance assessment is still considered difficult because there are many aspects of students that need to be considered [4].

Usually, the assessment technique used was in the form of a test. This type of assessment technique only needs to be utilised after students have carried out the learning process [6]. The implementation of the 4C's skills performance assessment is difficult because it involves all aspects of student competencies; whereas, the knowledge needed to develop the 4C's skills performance assessment instrument is still not fully understood. Considering this condition, the implementation of the assessment is still subjective. Assessment of learning is only performed quantitatively so that qualitative assessment that includes information about the strengths and weaknesses of students is difficult to implement [22]. The results of these preliminary studies and literature studies were then analyzed and compared with the ideal conditions.

\subsection{Design and Construction Stage}

After the data regarding analysis and exploration stage results were obtained, the researchers evaluate and analyze the data. The result of the evaluation of the processed data indicates that it is necessary to create a performance assessment instrument based on 4C's skills in STEM learning. Therefore, the researchers designed a performance assessment instrument in the form of a performance assessment rubric. The steps for making a performance assessment instrument product design are:

\subsubsection{Development of Specification}

The development of this instrument begins with determining the performance assessment instrument to be developed. The instrument used was an assessment rubric. In this study, researchers chose several thematic-based subjects to be taught to fifth grade students and grouped in a theme, namely Events in Life. The theme serves as a package of several subjects based on the analysis of core competencies and basic competencies listed in the curriculum. The subjects to be included in the theme are Science, Mathematics and Indonesian language.
Table 1. Basic Competencies Mapping

\begin{tabular}{|c|l|}
\hline Subjects & \multicolumn{1}{|c|}{ Kompetensi Dasar } \\
\hline \multirow{5}{*}{ Science } & $\begin{array}{l}\text { 3.7 Analyzing the effect of heat on changes in } \\
\text { temperature and shape of objects in everyday life. } \\
4.7 \text { Report the experimental results of the effect of } \\
\text { heat on objects. }\end{array}$ \\
\hline Mathematics \\
$\begin{array}{l}\text { 3.3 Explaining the comparison of two different } \\
\text { quantities (velocity as a ratio of distance to time, } \\
\text { discharge as a ratio of volume to time). } \\
4.3 \text { Solving problems related to the comparison of } \\
\text { two different quantities (velocity, discharge). }\end{array}$ \\
\hline \multirow{3}{*}{$\begin{array}{l}3.5 \text { Extracting important information from } \\
\text { historical narrative texts presented orally and in } \\
\text { writing using aspects: what, where, when, who, } \\
\text { why, and how. } \\
4.5 \text { Presenting important information from } \\
\text { historical narrative texts using aspects: what, } \\
\text { where, when, who, why, and how as well as } \\
\text { standard vocabulary and effective sentences. }\end{array}$} \\
\hline
\end{tabular}

Table 2. 4C's Skills Indicator (EdLeader21)

\begin{tabular}{|c|c|}
\hline Aspects & Aspect Indicators \\
\hline \multirow{3}{*}{ Critical Thinking } & Information and discovery \\
\cline { 2 - 2 } Creativity & Interpretation and analysis \\
\cline { 2 - 2 } & Creative production and innovation \\
\cline { 2 - 2 } Collaboration & Openness and courage to explore \\
\cline { 2 - 2 } & Idea generation \\
\cline { 2 - 2 } & Leadership and initiative \\
\hline \multirow{3}{*}{ Communication } & Teamwork \\
\cline { 2 - 2 } & Engaging in conversation and discussion \\
\cline { 2 - 2 } & Communicating in a diverse environment \\
\hline
\end{tabular}

2.2.2. Writing Process of the Instrument

There are things that must be considered when writing the 4C's performance assessment instrument, namely

\section{A. Outline}

Creating a performance instrument development product outline begins with determining the indicators for each performance. These indicators are determined by looking at skills process indicators and learning indicators based on basic competencies in the Indonesian curriculum and aspects of 4C's skills. There are 11 indicators of the four aspects used in this performance assessment rubric, namely: Information and discovery, interpretation and analysis, creative production and innovation, openness and courage to explore, idea generation, leadership and initiative, teamwork, responsibility and productivity, engaging in conversation and discussion, communicating in a diverse environment, giving an oral presentation. 


\section{B. Instrument Format}

The format of the instrument to be developed is in the form of a table containing performance aspects, student performance criteria, assessment indicators consisting of a score column and a description column, as well as information about the time.

\section{Determining the Instrument Scale}

The scale used in the performance assessment instrument developed is the rating scale. In the assessment instrument, there are 4 score options, namely 4, 3, 2, and 1 . These scores are described qualitatively in the description column. Students who demonstrate the highest performance are given a score of 4 and for students who do not demonstrate a performanceare given a score of 1 .

\section{Describing the Performance Indicators}

After determining the scale, the next step is to describe the performance indicators from the expected to the unexpected performance (gradually).

Table 3. Example of Rubric Instrument Format

\begin{tabular}{|c|c|c|c|c|c|}
\hline \multirow{2}{*}{ Aspect Indicator } & \multicolumn{4}{|c|}{ Scores } & \multirow{2}{*}{ Information } \\
\hline & 1 & 2 & 3 & 4 & \\
\hline $\begin{array}{l}\text { Information and } \\
\text { Discovery }\end{array}$ & $\begin{array}{l}\text { Show the inability } \\
\text { to explain the effect } \\
\text { of heat on the } \\
\text { temperature of an } \\
\text { object during } \\
\text { question and } \\
\text { answer session after } \\
\text { watching the video. }\end{array}$ & $\begin{array}{l}\text { Show the ability to } \\
\text { explain the effect of } \\
\text { heat on the } \\
\text { temperature of an } \\
\text { object in their own } \\
\text { words, but it is not } \\
\text { clear during the } \\
\text { question and } \\
\text { answer session after } \\
\text { watching the video. }\end{array}$ & $\begin{array}{l}\text { Show the ability to } \\
\text { explain the effect of } \\
\text { heat on the } \\
\text { temperature of an } \\
\text { object in their own } \\
\text { words during the } \\
\text { question and } \\
\text { answer session after } \\
\text { watching the video }\end{array}$ & $\begin{array}{l}\text { Show a thorough } \\
\text { understanding of } \\
\text { the effect of heat on } \\
\text { temperature of an } \\
\text { object by } \\
\text { explaining in their } \\
\text { own words during } \\
\text { question and } \\
\text { answer session after } \\
\text { watching the video. }\end{array}$ & $\begin{array}{c}\text { Situation: question } \\
\text { and answer session } \\
\text { with the teacher } \\
\text { after watching the } \\
\text { video. } \\
\text { (core activity stage } \\
2 \text { step 18) } \\
\text { Task: } \\
\text { presenting } \\
\text { information based } \\
\text { on findings } \\
\text { obtained through } \\
\text { video viewing } \\
\text { activities }\end{array}$ \\
\hline
\end{tabular}

Table 4. Draft of Performance Assessment Rubric (Critical Thinking)

\begin{tabular}{|c|c|c|c|c|c|}
\hline \multirow{2}{*}{$\begin{array}{c}\text { Aspect } \\
\text { Indicators }\end{array}$} & \multicolumn{4}{|c|}{ Scores } & \multirow{2}{*}{ Keterangan } \\
\hline & 1 & 2 & 3 & 4 & \\
\hline $\begin{array}{l}\text { Information } \\
\text { and } \\
\text { Discovery }\end{array}$ & $\begin{array}{l}\text { Show the inability } \\
\text { to explain the effect } \\
\text { of heat on the } \\
\text { temperature of an } \\
\text { object during } \\
\text { question and } \\
\text { answer session } \\
\text { after watching the } \\
\text { video. }\end{array}$ & $\begin{array}{l}\text { Show the ability to } \\
\text { explain the effect of } \\
\text { heat on the } \\
\text { temperature of an } \\
\text { object in their own } \\
\text { words, but it is not } \\
\text { clear during the } \\
\text { question and answer } \\
\text { session after } \\
\text { watching the video. }\end{array}$ & $\begin{array}{l}\text { Show the ability to } \\
\text { explain the effect } \\
\text { of heat on the } \\
\text { temperature of an } \\
\text { object in their own } \\
\text { words during the } \\
\text { question and } \\
\text { answer session } \\
\text { after watching the } \\
\text { video }\end{array}$ & $\begin{array}{l}\text { Show a thorough } \\
\text { understanding of } \\
\text { the effect of heat on } \\
\text { temperature of an } \\
\text { object by } \\
\text { explaining in their } \\
\text { own words during } \\
\text { question and } \\
\text { answer session after } \\
\text { watching the video. }\end{array}$ & $\begin{array}{l}\text { Situation: question and } \\
\text { answer session with the } \\
\text { teacher after watching the } \\
\text { video. } \\
\text { (core activity stage } 2 \text { step } \\
18 \text { ) } \\
\text { Task: } \\
\text { conveying information } \\
\text { based on findings } \\
\text { obtained through video } \\
\text { viewing activities }\end{array}$ \\
\hline $\begin{array}{l}\text { Interpretation } \\
\text { and Analysis }\end{array}$ & $\begin{array}{l}\text { Does not convey } \\
\text { important } \\
\text { information from } \\
\text { the historical } \\
\text { narrative text about } \\
\text { the events of the } \\
\text { battle of the } \\
\text { Arafura Sea. }\end{array}$ & $\begin{array}{l}\text { Convey } 1 \text { important } \\
\text { information from the } \\
\text { historical narrative } \\
\text { text about the events } \\
\text { of the battle of the } \\
\text { Arafura Sea } \\
\text { correctly. }\end{array}$ & $\begin{array}{c}\text { Convey } 2 \\
\text { important } \\
\text { information from } \\
\text { the historical } \\
\text { narrative text about } \\
\text { the events of the } \\
\text { battle of the } \\
\text { Arafura Sea } \\
\text { correctly. }\end{array}$ & $\begin{array}{l}\text { Convey } 2 \text { important } \\
\text { information from } \\
\text { the historical } \\
\text { narrative text about } \\
\text { the events of the } \\
\text { battle of the } \\
\text { Arafura Sea } \\
\text { correctly. }\end{array}$ & $\begin{array}{l}\text { Situation: question and } \\
\text { answer session with the } \\
\text { teacher. } \\
\text { (core activity stage } 1 \text { step } \\
\text { 10) } \\
\text { Task: convey } \\
\text { interpretation and } \\
\text { analysis of the events of } \\
\text { the battle of the Arafura } \\
\text { Sea }\end{array}$ \\
\hline
\end{tabular}


Table 5. Draft of Performance Assessment Rubric (Creativity)

\begin{tabular}{|c|c|c|c|c|c|}
\hline \multirow{2}{*}{$\begin{array}{c}\text { Aspect } \\
\text { Indicators }\end{array}$} & \multicolumn{4}{|c|}{ Scores } & \multirow{2}{*}{ Information } \\
\hline & 1 & 2 & 3 & 4 & \\
\hline $\begin{array}{l}\text { Creative } \\
\text { Production } \\
\text { and } \\
\text { Innovation }\end{array}$ & $\begin{array}{c}\text { Draw and } \\
\text { decorate the } \\
\text { design of a } \\
\text { steam powered } \\
\text { boat } \\
\text { manufacturing } \\
\text { process but } \\
\text { cannot make a } \\
\text { steam powered } \\
\text { boat product. }\end{array}$ & $\begin{array}{l}\text { Draw and decorate } \\
\text { the design of a steam } \\
\text { powered boat } \\
\text { manufacturing } \\
\text { process and can } \\
\text { make a steam } \\
\text { powered boat } \\
\text { product but it cannot } \\
\text { function. }\end{array}$ & $\begin{array}{l}\text { Draw and decorate } \\
\text { the design of a steam } \\
\text { powered boat } \\
\text { manufacturing } \\
\text { process and can } \\
\text { make a steam } \\
\text { powered boat } \\
\text { product and it can } \\
\text { function. }\end{array}$ & $\begin{array}{l}\text { Draw and decorate the } \\
\text { design of a steam } \\
\text { powered boat } \\
\text { manufacturing process } \\
\text { and can make a steam } \\
\text { powered boat product } \\
\text { and it can function, and } \\
\text { provide an explanation of } \\
\text { the innovation process } \\
\text { and how the product } \\
\text { meets the challenges. }\end{array}$ & $\begin{array}{c}\text { Situation: while } \\
\text { conducting an } \\
\text { experiment of making } \\
\text { a product } \\
\text { (core activity stage } 3 \\
\text { step 24) } \\
\text { Task: draw a design of } \\
\text { a steam powered boat } \\
\text { manufacturing process } \\
\text { and make a steam } \\
\text { powered boat product. }\end{array}$ \\
\hline $\begin{array}{l}\text { Openness and } \\
\text { Courage to } \\
\text { Explore }\end{array}$ & $\begin{array}{l}\text { Not responsive } \\
\text { to input, does not } \\
\text { show confidence } \\
\text { and does not } \\
\text { develop } \\
\text { curiosity when } \\
\text { retrying. }\end{array}$ & $\begin{array}{l}\text { Not responsive to } \\
\text { input, does not show } \\
\text { confidence but } \\
\text { develops curiosity } \\
\text { when retrying }\end{array}$ & $\begin{array}{l}\text { Be responsive to } \\
\text { input, do not show } \\
\text { confidence and } \\
\text { develop curiosity } \\
\text { when retrying. }\end{array}$ & $\begin{array}{l}\text { Be responsive to input, } \\
\text { show confidence and } \\
\text { develop curiosity when } \\
\text { retrying. }\end{array}$ & $\begin{array}{l}\text { Situation: when } \\
\text { retrying } \\
\text { (experimenting again) } \\
\text { (core activity stage } 5 \\
\text { step } 38 \text { ). } \\
\text { Task: make a steam } \\
\text { powered boat product. }\end{array}$ \\
\hline $\begin{array}{c}\text { Idea } \\
\text { Generation }\end{array}$ & $\begin{array}{l}\text { Does not explain } \\
\text { and does not } \\
\text { provide } \\
\text { solutions when } \\
\text { there is a } \\
\text { problem. }\end{array}$ & $\begin{array}{c}\text { Describes an } \\
\text { investigation into } \\
\text { barriers when testing } \\
\text { steam powered boat } \\
\text { media but found no } \\
\text { solution to improve } \\
\text { the product. }\end{array}$ & $\begin{array}{l}\text { Describes an } \\
\text { investigation into } \\
\text { barriers when testing } \\
\text { steam powered boat } \\
\text { media but is slow to } \\
\text { find solution to } \\
\text { improve the product. }\end{array}$ & $\begin{array}{c}\text { Provides a } \\
\text { comprehensive overview } \\
\text { of an investigation into } \\
\text { barriers when testing } \\
\text { steam powered boat } \\
\text { media, quickly finds } \\
\text { solution to improve the } \\
\text { product. }\end{array}$ & $\begin{array}{l}\text { Situation: when testing } \\
\text { the steam powered } \\
\text { boat product } \\
\text { (core activity stage } 4 \\
\text { step } 36 \text { ). } \\
\text { Task: operates steam } \\
\text { powered boat product. }\end{array}$ \\
\hline
\end{tabular}

Table 6. Draft of Performance Assessment Rubric (Collaboration)

\begin{tabular}{|c|c|c|c|c|c|}
\hline \multirow{2}{*}{$\begin{array}{c}\text { Aspect } \\
\text { Indicators }\end{array}$} & \multicolumn{4}{|c|}{ Scores } & \multirow{2}{*}{ Information } \\
\hline & 1 & 2 & 3 & 4 & \\
\hline $\begin{array}{l}\text { Leadership } \\
\text { and Initiative }\end{array}$ & $\begin{array}{l}\text { Indifferent to } \\
\text { group } \\
\text { performance } \\
\text { results. }\end{array}$ & $\begin{array}{l}\text { Shows initiative, is } \\
\text { indifferent in } \\
\text { examining work and } \\
\text { does not provide } \\
\text { direction and solutions } \\
\text { to group performance. }\end{array}$ & $\begin{array}{l}\text { Show an attitude of } \\
\text { initiative, indifferent } \\
\text { to the results of the } \\
\text { work but provide } \\
\text { direction and } \\
\text { solutions to group } \\
\text { performance. }\end{array}$ & $\begin{array}{l}\text { Show an attitude of } \\
\text { initiative, play an } \\
\text { active role in } \\
\text { examining work, } \\
\text { providing direction } \\
\text { and solutions to } \\
\text { group performance. }\end{array}$ & $\begin{array}{c}\text { Situation: when } \\
\text { drawing a process } \\
\text { design for a steam } \\
\text { powered boat } \\
\text { (core activity stage } 3 \\
\text { step 24) } \\
\text { Task: to lead the group } \\
\text { in any work that is } \\
\text { being done. }\end{array}$ \\
\hline Teamwork & $\begin{array}{l}\text { Play a passive role } \\
\text { when doing the } \\
\text { experiment. }\end{array}$ & $\begin{array}{l}\text { Does not show an } \\
\text { understanding of the } \\
\text { needs of group } \\
\text { members in planning } \\
\text { or preparing tools and } \\
\text { materials, but discuss } \\
\text { in making decisions } \\
\text { when conducting } \\
\text { experiments. }\end{array}$ & $\begin{array}{l}\text { Shows an } \\
\text { understanding of the } \\
\text { needs of group } \\
\text { members in planning } \\
\text { or preparing tools } \\
\text { and materials, but } \\
\text { does not discuss in } \\
\text { making decisions } \\
\text { when conducting } \\
\text { experiments. }\end{array}$ & $\begin{array}{l}\text { Shows an } \\
\text { understanding of the } \\
\text { needs of group } \\
\text { members in planning } \\
\text { or preparing tools } \\
\text { and materials and } \\
\text { discusses in making } \\
\text { decisions when } \\
\text { conducting } \\
\text { experiments. }\end{array}$ & $\begin{array}{l}\text { Situation: while } \\
\text { preparing the tools and } \\
\text { materials needed } \\
\text { (core activity stage } 3 \\
\text { step 21) } \\
\text { Task: write down tools } \\
\text { and materials for } \\
\text { making a } \\
\text { steam-powered boat } \\
\text { product }\end{array}$ \\
\hline $\begin{array}{l}\text { Responsibility } \\
\text { and } \\
\text { Productivity }\end{array}$ & $\begin{array}{l}\text { Does not show an } \\
\text { attitude of } \\
\text { responsibility } \\
\text { towards } \\
\text { assignments, does } \\
\text { not submit their } \\
\text { assignments } \\
\text { completely, and } \\
\text { does not help } \\
\text { other students who } \\
\text { are in need when } \\
\text { making a steam } \\
\text { powered boat. }\end{array}$ & $\begin{array}{c}\text { Shows a responsible } \\
\text { attitude towards } \\
\text { assignments, dose not } \\
\text { submit their } \\
\text { assignments } \\
\text { completely, and does } \\
\text { not help other students } \\
\text { who are in need when } \\
\text { making a steam } \\
\text { powered boat. }\end{array}$ & $\begin{array}{l}\text { Shows a responsible } \\
\text { attitude towards the } \\
\text { assignment, submits } \\
\text { the assignment } \\
\text { completely, but does } \\
\text { not help other } \\
\text { students who are in } \\
\text { need when making a } \\
\text { steam powered boat. }\end{array}$ & $\begin{array}{l}\text { Shows a responsible } \\
\text { attitude towards the } \\
\text { assignment, submits } \\
\text { the assignment } \\
\text { completely, helps } \\
\text { other students who } \\
\text { are in need when } \\
\text { making a steam } \\
\text { powered boat. }\end{array}$ & $\begin{array}{c}\text { Situation: when } \\
\text { making a } \\
\text { steam-powered boat } \\
\text { product } \\
\text { (core activity stage } 4 \\
\text { step } 31 \text { ) } \\
\text { Task: make a steam } \\
\text { powered boat product. }\end{array}$ \\
\hline
\end{tabular}


Table 7. Draft of Performance Assessment Rubric (Communication)

\begin{tabular}{|c|c|c|c|c|c|}
\hline \multirow{2}{*}{$\begin{array}{c}\text { Aspect } \\
\text { Indicators }\end{array}$} & \multicolumn{4}{|c|}{ Scores } & \multirow{2}{*}{ Information } \\
\hline & 1 & 2 & 3 & 4 & \\
\hline $\begin{array}{l}\text { Engaging in } \\
\text { Conversation } \\
\text { and Discussion }\end{array}$ & $\begin{array}{l}\text { Not able to } \\
\text { communicate in } \\
\text { groups, and does } \\
\text { not show respect } \\
\text { for the opinions of } \\
\text { other students } \\
\text { during the learning } \\
\text { process. }\end{array}$ & $\begin{array}{l}\text { Not able to } \\
\text { communicate in } \\
\text { groups and get out of } \\
\text { the topic, but shows } \\
\text { respect for the } \\
\text { opinions of other } \\
\text { students during the } \\
\text { learning process. }\end{array}$ & $\begin{array}{c}\text { Able to } \\
\text { communicate in } \\
\text { groups according to } \\
\text { the topic that } \\
\text { should be } \\
\text { discussed, but does } \\
\text { not show respect } \\
\text { for the opinions of } \\
\text { other students } \\
\text { during the learning } \\
\text { process. }\end{array}$ & $\begin{array}{c}\text { Able to } \\
\text { communicate in } \\
\text { groups according to } \\
\text { the topic that } \\
\text { should be } \\
\text { discussed, and } \\
\text { shows respect for } \\
\text { the opinions of } \\
\text { other students } \\
\text { during the learning } \\
\text { process. }\end{array}$ & $\begin{array}{l}\text { Situation: during group } \\
\text { discussion while } \\
\text { collecting tools and } \\
\text { materials. } \\
\text { (core activity stage } 3 \\
\text { step 21) } \\
\text { Task: group discussion. }\end{array}$ \\
\hline $\begin{array}{l}\text { Communicating } \\
\text { in a diverse } \\
\text { environment }\end{array}$ & $\begin{array}{l}\text { Does not show } \\
\text { understanding of } \\
\text { other students' } \\
\text { opinions, unable to } \\
\text { accept that other } \\
\text { students have } \\
\text { different opinions, } \\
\text { and unable to } \\
\text { communicate with } \\
\text { students who have } \\
\text { these differences of } \\
\text { opinion during the } \\
\text { discussion of the } \\
\text { experimental } \\
\text { results report. }\end{array}$ & $\begin{array}{l}\text { Shows an } \\
\text { understanding of the } \\
\text { differences in } \\
\text { opinions of other } \\
\text { students, but is } \\
\text { unable to accept that } \\
\text { other students have } \\
\text { different opinions, } \\
\text { and is unable to } \\
\text { communicate with } \\
\text { students who have } \\
\text { these differences of } \\
\text { opinion during the } \\
\text { discussion of the } \\
\text { experimental results } \\
\text { report. }\end{array}$ & $\begin{array}{c}\text { Shows an } \\
\text { understanding of } \\
\text { other students' } \\
\text { differences of } \\
\text { opinion, unable to } \\
\text { accept that other } \\
\text { students having } \\
\text { different opinions } \\
\text { but communicating } \\
\text { with other students } \\
\text { who have these } \\
\text { differences of } \\
\text { opinion during the } \\
\text { discussion of the } \\
\text { experimental } \\
\text { results report. }\end{array}$ & $\begin{array}{c}\text { Shows } \\
\text { understanding of } \\
\text { other students' } \\
\text { differences in } \\
\text { opinion, being able } \\
\text { to accept that other } \\
\text { students have } \\
\text { different opinions } \\
\text { and communicating } \\
\text { with other students } \\
\text { who have these } \\
\text { differences of } \\
\text { opinion during the } \\
\text { discussion of the } \\
\text { experimental } \\
\text { results report. }\end{array}$ & $\begin{array}{c}\text { Situation: when } \\
\text { discussing the } \\
\text { experimental results } \\
\text { report. } \\
\text { (core activity stage } 5 \\
\text { step 46) } \\
\text { Task: discussion of the } \\
\text { experimental results } \\
\text { report. }\end{array}$ \\
\hline $\begin{array}{l}\text { Giving an Oral } \\
\text { Presentation. }\end{array}$ & $\begin{array}{l}\text { Does not } \\
\text { understand the } \\
\text { results of the } \\
\text { discussion and the } \\
\text { volume of the voice } \\
\text { cannot be heard so } \\
\text { that the delivery of } \\
\text { the results of the } \\
\text { discussion cannot } \\
\text { be understood by } \\
\text { other students. }\end{array}$ & $\begin{array}{l}\text { Lack of } \\
\text { understanding of the } \\
\text { results of the } \\
\text { discussion and the } \\
\text { volume of voices can } \\
\text { be heard, but the } \\
\text { delivery of the results } \\
\text { of the discussion } \\
\text { cannot be understood } \\
\text { by other students. }\end{array}$ & $\begin{array}{l}\text { Understands the } \\
\text { results of the } \\
\text { discussion and the } \\
\text { volume of the voice } \\
\text { cannot be heard } \\
\text { enough, but the } \\
\text { delivery of the } \\
\text { results of the } \\
\text { discussion is easily } \\
\text { understood by other } \\
\text { students. }\end{array}$ & $\begin{array}{l}\text { Properly } \\
\text { understand the } \\
\text { results of the } \\
\text { discussion and the } \\
\text { volume of the voice } \\
\text { can be heard so that } \\
\text { it can be } \\
\text { understood by other } \\
\text { students. }\end{array}$ & $\begin{array}{l}\text { Situation: when } \\
\text { presenting the results of } \\
\text { the experimental report } \\
\text { discussion. } \\
\text { (core activity stage } 5 \\
\text { step 46) } \\
\text { Task: present the results } \\
\text { of the discussion in front } \\
\text { of the class. }\end{array}$ \\
\hline
\end{tabular}

\subsection{Evaluation and Reflection Stage}

After the rubric has been completed and has been validated, the next step was to test the rubric to determine the extent to which the rubric was effective in assessing student performance during the learning process that the researchers had developed. After the performance assessment instrument that was made by the researcher was revised based on validation by the experts, the next step was to conduct a trial. The trial was conducted on fifth grade students of Indonesian elementary schools, to be precise in Ciamis Regency, West Java Province. In the process of testing the performance assessment rubric for individuals, because of the limitations of student performance assessment, only five students were observed by the observer to make the assessment easier.

Data from the recapitulation of scores given by 7 observers to 5 students can be seen as follows:
Table 8. Kendall's 4C's Test Results

\begin{tabular}{|c|c|c|c|c|c|}
\hline \multirow{2}{*}{$\begin{array}{c}\text { Performance } \\
\text { Aspects }\end{array}$} & \multicolumn{5}{|c|}{ Results } \\
\cline { 2 - 6 } & S1 & S2 & S3 & S4 & S5 \\
\hline C1 & 0,02 & 0,16 & 0,04 & 0,02 & 0,04 \\
\hline C2 & 0,02 & 0,04 & 0,01 & 0,02 & 0,03 \\
\hline C3 & 0,21 & 0,05 & 0,03 & 0,02 & 0,03 \\
\hline C4 & 0,04 & 0,04 & 0,10 & 0,03 & 0,03 \\
\hline
\end{tabular}

Based on the results of the Kendall's 4C's test, the agreement of the Kendall test results (concordance) means that the performance assessment rubric based on 4C's skills is feasible to use. The average value shows the value of Asymp.Sig <0.05, so there is agreement among the observers in assessing the attributes. However, there are still some efforts needed to improve the product further. Apart from the agreement test, the researchers also reflected on the product through interviews with the observer. From the interview, there were several 
suggestions for researchers, including the use of words or sentences that were simplified so that they were easy to understand. Then, the description of each performance aspect indicator should be more tailored to the competencies of students. After discovering the shortcomings, the researchers made several revisions regarding the words used. However, the overall results from interviews with observers show good responses, this 4C's skills performance assessment rubric can be used as an assessment tool to develop 21 st century skills in STEM-based learning.

\section{Conclusions}

The 4C's skills performance assessment instrument in the form of an assessment rubric developed by researchers can be used by teachers for objective assessment based on each existing criterion and indicator. In addition, students will have a reference about what the teacher expects based on the assessment rubric; thus, students can show their best performance. The $4 \mathrm{C}$ assessment instrument is suitable for use as a learning tool because the test results show an alignment between the indicators on the skills shown in STEM learning activities. The development of the 4C's skills performance assessment instrument for STEM learning can be further developed on other themes or sub-themes.

\section{Acknowledgement}

Researchers would like to thank the experts who have provided suggestions for improving the performance assessment rubric based on the 4C's skills.

\section{REFERENCES}

[1] Anwari, I., Yamada, S., Unno, M., \& Saito, T. (2015). Implementation of Authentic Learning and Assessment through STEM Education Approach to Improve Students' Metacognitive Skills. K-12 STEM Education. 1(3), 123-136.

[2] A. P. Carneyale, H. Smith, M. Melton (2014). STEM, Washington DC, Georgetown University Center on Education and the Workforce.

[3] Ardianti, S., Sulisworo, D., Pramudya, Y., \& Raharjo, w. (2020). The Impact of the use of STEM Education Approach on the Blended Learning to Improve Student's Critical Thinking Skills. Universal Journal of Educational Research. 8, 24-32. https://doi.org/10.13189/ujer.2020.081503

[4] Cahyono. A. E, Evaluasi Pelaksanaan Authentic Assessment Berdasarkan Kurikulum 2013 dalam Pembelajaran Ekonomi di SMA Islam Al-Hidayah Jember, Equilibrium: Jurnal Ilmiah Ekonomi dan Pembelajarannya, Vol.5, No.1, 1, 2017.

[5] Griffin. P., McGaw. B \& Care, E. Assessment and teaching of 21 st century skills, Dordrecht: Springer, 2012.

[6] Hajaroh. S., Islam. U \& Mataram, N, Kesulitan Guru dalam Mengimplementasikan, Vol.10, No.2, 131-152. 2018.

[7] Hamdu. Ghullam, Perangkat Pembelajaran Berbasis Masalah Secara Tematik di Sekolah Dasar, Bandung: Pelangi Press, 2016.

[8] Han. S., Capraro. R \& Capraro, M. M, How Science, Technology, Engineering, and Mathematics (Stem) Project-Based Learning (Pbl) Affects High, Middle, and Low Achievers Differently: the Impact of Student Factors on Achievemen, International Journal of Science and Mathematics Education, Vol.13, No.5, 1089-1113, 2015.

[9] Hart, Diane. (1994). Authentic Assessment A handbook for Educators. California, New York: Addison Wesley Publishing Company.

[10] Honey. M., Pearson. G \& Schweingruber. H, STEM Integration in K-12 Education, 2014.

[11] Johnson. D \& Johnson. R, Meaningful Assessment. Boston: Allyn and Bacon, 2002.

[12] Koenig. J, A, 21 ST CENTURY SKILLS Summary of a Workshop. In Social Sciences, 2011.

[13] Kunandar, Penilaian Autentik (Penilaian Hasil Belajar Peserta Didik Berdasarkan Kurikulum 2013. Bandung: PT Remaja Rosdakarya, 2013.

[14] Marzano, R. J. (1993). Designing a New Taxonomy of Educational Objectives. Thousand Oaks, CA: Corwin Press.

[15] McKenney. S. R, Conducting Educational Design Research. New York: Routledge, 2012.

[16] Menteri Pendidikan dan Kebudayaan RI, Permendikbud No 66 Tahun 2013 tentang Standar Penilaian Pendidikan, 2013.

[17] M. S. Corlu, R. M. Capraro, M. M. Capraro. Introducing STEM Education: Implications for Education Our Teachers for the Age of Innovation. Egitim ve Bilim. Journal of Education and Science, Vol. 39, No.171, 74-85, 2014.

[18] Musa. F., Mufti. N., Latiff. R. A., \& Amin. M. M,. (2013). Project-based Learning (PjBL): Inculcating Soft Skills in 21 st Century Workplace. Procedia - Social and Behavioral Sciences, Vol.59, 565-573.

[19] Nurlenasari. Lidinillah, G. Hamdu, Assessing 21st century skills of fourth-grade student in STEM learning. Journal of Physics: Conference Series, 2019.

[20] Pantiwati, Y. (2013). Authentic Assessment for Improving Cognitive Skill , Critical- Creative Thinking and Meta-Cognitive Awareness. Journal of Education and Practice, 4(14), 1-10.

[21] Partnership for 21st Century Skills. 2008. 21st Century Skills, Education \& Competitiveness: A Resource And Policy Guide. Tucson, AZ: Author

[22] Sani. R. A, Penilaian Autentik. Bandung: Bumi Aksara, 2016.

[23] Soh, T. M. T., Arsada, N. M., \& Osman, K. 2010. "The Relationship of 21st Century Skills on Students' Attitude and Perception towards Physics". Procedia Social and Behavioral Sciences, 7: 546-554. Retrieved from 
https://www.sciencedirect.com/science/article/pii/S1877042 81002077X

[24] Sunardi, D. K., Sugiarti T., Yudianto, E. \& Nurmaharani, R. 2017. "Pengembangan Indikator 4c's yang Selaras dengan
Kurikulum 2013 pada Mata Pelajaran Matematika SMA/MA Kelas X Semester 1". AdMathEdu, 7 (2): 197-210. Retrieved from https://jurnal.unej.ac.id/index.php/kadikma/article/vie w/5277 